Atıf İçin: Kayakökü H, 2021. Bitlis Aygır Gölü (Türkiye) Yüzey Su Örneklerinde Radon Konsantrasyonunun Belirlenmesi. Iğdır Üniversitesi Fen Bilimleri Enstitüsü Dergisi, 11(2): 1040-1049.

To Cite: Kayakökü H, 2021. Determination of Radon Concentrations in Surface Water Samples of Aygır Lake in Bitlis (Turkey). Journal of the Institute of Science and Technology, 11(2): 1040-1049.

\title{
Determination of Radon Concentrations in Surface Water Samples of Aygır Lake in Bitlis (Turkey) Halime KAYAKÖKÜ1,*
}

\begin{abstract}
Aygir Lake is located in the province of Bitlis, Adilcevaz, in the east of Turkey. It is located on the south side of Süphan Mountain and is a tectonically formed lake. Since the waters of Aygir Lake are fresh, it is an important water source in terms of meeting the water needs of the agricultural areas in the south. For this reason, it was tried to determine whether the water of the lake would pose a health risk in terms of radon if it was consumed as drinking water and used in agricultural activities and fish farming. In the study, radon $\left({ }^{222} \mathrm{Rn}\right)$ concentrations, the annual effective dose rate (AED) and the amount of dose the stomach takes (SED) in the surface water samples taken from Aygir Lake were tried to be determined. For this purpose, water samples were taken from 13 different points in the lake. Saphymo Gmbh AlphaGUARD Professional radon monitor was used to measure the radon activities of the water samples. As a result of the measurements, it is seen that the radon concentrations vary between $0.15 \pm 0.01 \mathrm{~Bq} \mathrm{~L}^{-1}$ and $0.71 \pm 0.08 \mathrm{~Bq} \mathrm{~L}^{-1}$. In addition, in the study, AED values ranged from $0.38 \pm 0.03 \mathrm{nSv} \mathrm{y}^{-1}$ to $1.81 \pm 0.20 \mathrm{nSv} \mathrm{y}^{-1}$, while SED values ranged from $0.05 \pm 0.00 \mathrm{nSv} \mathrm{y}^{-1}$ to 0.22 $\pm 0.02 \mathrm{nSv} \mathrm{y}^{-1}$. When the results obtained are compared with the average international values, it is noticed that the results are below these values.
\end{abstract}

Keywords: Aygır Lake, radon, alphaGUARD, surface water

\section{Bitlis Aygır Gölü (Türkiye) Yüzey Su Örneklerinde Radon Konsantrasyonunun Belirlenmesi}

ÖZET: Aygır Gölü, Türkiye'nin doğusunda, Bitlis'in Adilcevaz ilçesinde yer almaktadır. Süphan Dağı'nın güney tarafinda yer almakta olup, tektonik oluşumlu bir göldür. Suları tatlı olduğu için güneyindeki tarım alanlarının su ihtiyacını karşılaması bakımından Aygır Gölü önemli bir su kaynağıdır. Bu sebeple, göl suyunun içme suyu olarak tüketilmesi, tarımsal faaliyetlerde ve balık yetştiriciliğinde kullanılması durumunda, radon açısından, sağlık için risk oluşturup oluşturmayacağı belirlenmeye çalışılmıştır. Çalışmada, Aygır Gölü'nden alınan yüzey su örneklerinin radon $\left({ }^{222} \mathrm{Rn}\right)$ konsantrasyonları, y1llık etkin doz oranı (AED) ve midenin aldığ 1 doz miktarı (SED) belirlenmeye çalışılmıştır. Bu amaçla, gölde 13 farklı noktadan su örnekleri alınmıştır. Su örneklerinin ${ }^{222} \mathrm{Rn}$ aktivite konsantrasyonlarının ölçülmesinde Saphymo Gmbh AlphaGUARD Professional radon monitörü kullanılmıştır. Ölçümler sonucunda radon konsantrasyonlarının, $0,15 \pm 0,01 \mathrm{~Bq} \mathrm{~L}^{-1}$ ile $0,71 \pm 0,08 \mathrm{~Bq} \mathrm{~L}^{-1}$ aralığında değiştiği görülmektedir. Ayrıca çalışmada AED değerleri $0,38 \pm 0,03 \mathrm{nSv} \mathrm{y}^{-1}$ ile $1,81 \pm 0,20 \mathrm{nSv} \mathrm{y}^{-1}$, SED değerleri 0,05 $\pm 0,00 \mathrm{nSv} \mathrm{y}^{-1}$ ile $0,22 \pm 0,02 \mathrm{nSv} \mathrm{y}^{-1}$ arasında değişmektedir. Elde edilen sonuçlar uluslararas önerilen değerler ile kıyaslandığı zaman, sonuçların, bu değerlerin altında olduğu görülmektedir.

Anahtar Kelimeler: Aygır Gölü, radon, alphaGUARD, yüzey su

${ }^{1}$ Halime KAYAKÖKÜ (Orcid ID: 0000-0003-4036-4012), Bitlis Eren University, Faculty of Arts and Sciences, Department of Physics, Bitlis, Turkey.

*Sorumlu Yazar / Corresponding Author: Halime KAYAKÖKÜ, e-mail: hkayakoku@ beu.edu.tr 


\section{INTRODUCTION}

Water plays an important role in the life of living beings. The natural radioactivity of the water comes from the radioactive masses or minerals through which water flows. In natural waters, the uranium family is more common than the actinium and thorium family (Şahin, 2004).

${ }^{238} \mathrm{U}$ is the main component of natural uranium in the earth's crust $(99.275 \%)$. Radon $\left({ }^{222} \mathrm{Rn}\right)$ is the first gas isotope in the ${ }^{238} \mathrm{U}$ decay chain. In parallel with this, thoron $\left({ }^{220} \mathrm{Rn}\right)$ and actinon $\left({ }^{219} \mathrm{Rn}\right)$ appear as the first gas isotopes in the ${ }^{232} \mathrm{Th}$ and ${ }^{235} \mathrm{U}$ decay series. The decay of radon by alpha propagation creates three short-lived isotopes. These are ${ }^{218} \mathrm{Po},{ }^{214} \mathrm{~Pb}$ and ${ }^{214} \mathrm{Bi}$ (Valkovic, 2000). Radon is a colorless, odorless radioactive gas that cannot be detected by sensory organs. It is found more or less almost everywhere in nature. Radon has a half-life of 3.82 days (George, 2007). Radon gas spreads through diffusion to the soil and from there to the atmosphere or environment. With the accumulation of the gas, the radon density can reach critical values in closed or poorly ventilated places. Radon poses many dangers, especially lung cancer, when exposed to high doses (UNSCEAR, 1993; WHO, 2004; USEPA, 2011).

There are many methods of measuring radon. Usually, alpha count is used to measure radon gas and radon products. Radon measurement methods are divided into two as active and passive methods (Urban and Piesch, 1981). In the active measurement method, alpha particles are counted. Active measurement method requires devices such as electronic systems, pumps, power supplies. Ion chambers, scintillation cells or spectroscopic counting devices are used in the active system. AlphaGUARD measuring device works on the principle of active measurement method. In the passive measurement method, indirect measurements are made. In the passive measurement method, thermoluminescence detectors or solid state nuclear trace detectors cellulose nitrate (LR-115) or allyl diglycol carbonate (CR39) are used.

In Turkey, many studies have been made for determining the radon concentration in water. At the same time, in different parts of the world, there are various studies in which the radioactivity of utility water, well water and thermal water are measured resulting dose calculations (Gosink et al., 1990; AlMasri and Blackburn, 1999; Karahan et al., 2000; Çevik et al., 2006; Ereeş et al., 2006; Baykara and Dogru, 2006; Tarim et al., 2011; Yalcin et al., 2011; Bal et al., 2017).

According to WPCR (Water Pollution Control Regulation), Aygir Lake water was found in the first class quality water. It has been observed that the lake water complies with the limit values given by EPA (500 $\mathrm{mg} \mathrm{L}^{-1}$ ) and WHO (1000 $\mathrm{mg} \mathrm{L}^{-1}$ ) (Tebbutt, 1998; WPCR, 2004).

The purpose of the present study is to determine the radon concentrations, the annual effective dose rates and the amount of dose the stomach takes of surface water samples taken from Aygir Lake located in Adilcevaz district of Bitlis province. Thus, it will be attempted to determine whether the lake water will pose a health risk in terms of radon if it is consumed as drinking water and used in agricultural activities and fish farming. Radon concentration levels were measured with the Saphymo Gmbh AlphaGUARD Professional radon monitor using the active measurement method.

\section{MATERIALS AND METHODS}

\section{Sampling and Measurement}

Aygir Lake is located in the province of Bitlis, Adilcevaz, in the east of Turkey. The lake is at the

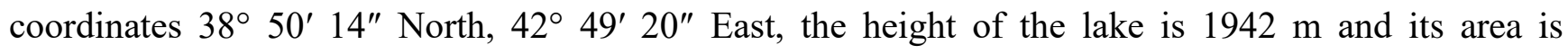
approximately $1.6 \mathrm{~km}^{2}$ (Dogu and Deniz, 2015; Çavuş, 2018). It is located on the south side of Süphan Mountain and is a tectonically formed lake. The lake is fed by rain and snow waters as well as groundwater. There are no streams or strong springs that constantly carry water to the lake. Since its 
waters are fresh, Aygir Lake is an important water resource in terms of meeting the water needs of the agricultural areas in the south. Additionally, this lake, which contains different fish species, plays an important role in terms of fishing.

In this study, samples were taken from 13 different points from the lake in June 2020 from a depth of $20 \mathrm{~cm}$ from the surface and placed in 1 liter polyethylene bottles. After the samples brought to the laboratory, they were filtered by filter paper, and then the samples were measured and analyzed immediately. Sampling points are shown in Figure 1.

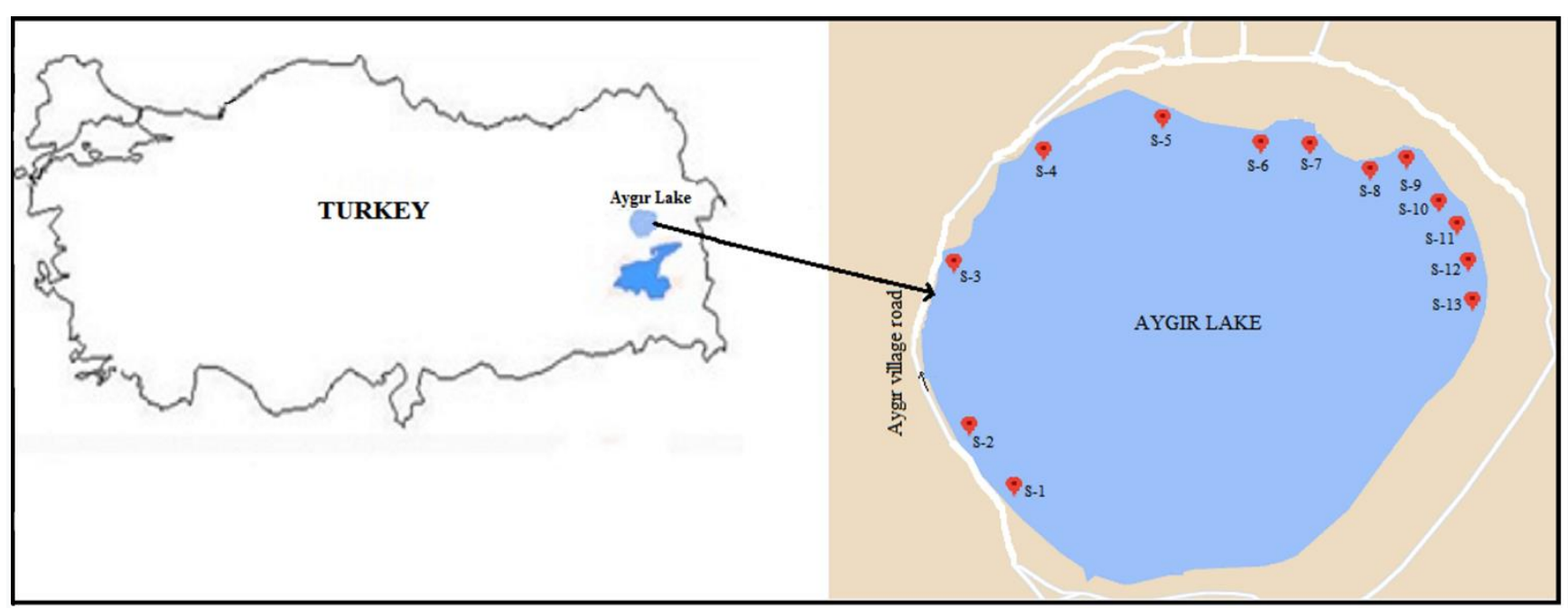

Figure 1. Water sampling points from Aygır Lake

Figure 2 shows an view of the AlphaGUARD radon measurement system in water.

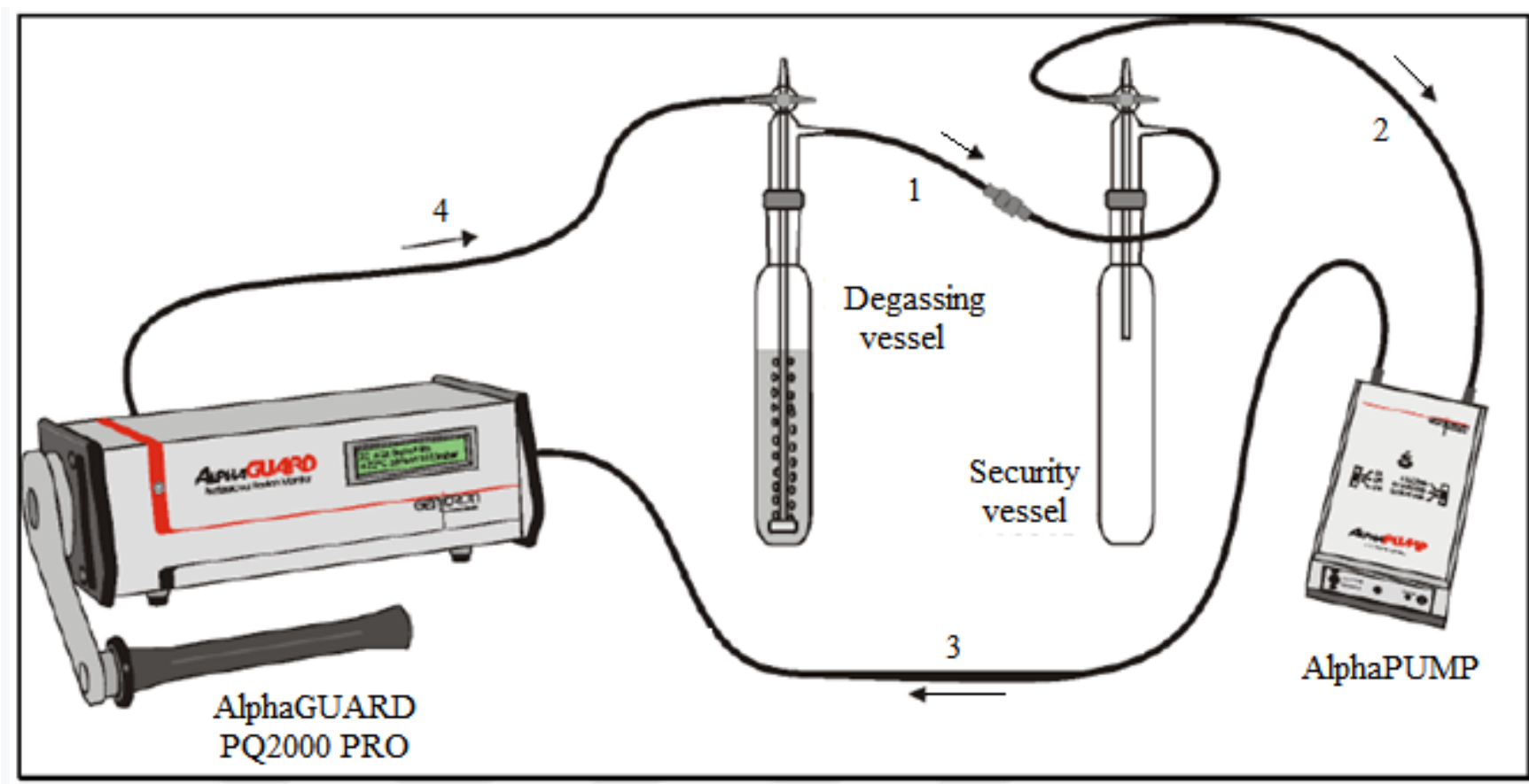

Figure 2. The AlphaGUARD radon measurement setup in water (GENITRON INSTRUMENTS, 2001; Tanrıverdi, 2016)

Radon measurement system in waters consists of AquaKIT, AlphaPUMP, AlphaGUARD PQ2000 PRO. Radon concentration measurement can be made with AlphaGUARD radon detector in the range of $2-2,106 \mathrm{~Bq} \mathrm{~m}^{-3}$. Despite this wide range, there is a $3 \%$ margin of error resulted from the system itself. 
The AlphaGUARD detector, which gives the measurement results in $\mathrm{Bq} \mathrm{m}^{-3}$, can simultaneously measure three different climatic parameters such as temperature, atmospheric pressure and humidity. The units of these parameters are ${ }^{\circ} \mathrm{C}$, mbar and $\mathrm{rH} \%$, respectively (Genrich, 2006). The measurement was made for 10 minutes before filling the purification bottle section with the water sample. The result of this measurement is $\mathrm{C}_{0}$ (natural background value). The clarification vessel was filled with $100 \mathrm{ml}$ of water sample. The measurements made for 10 minutes while the pump was on and 20 minutes while the pump was off which makes 30 minutes in total (Nikolopoulos et al., 2010; Meisenberg et al., 2017). The concentration value obtained as a result of this measurement was also recorded as $\mathrm{C}_{\text {air. }}$ Sample and background counts were performed three times for each samples. Before filling each sample, the system, gases etc. are cleaned in order to carry out the measurement process. Cleaning the measuring device continued until the radon value reached ambient concentration. After this step, the measurement procedure was made again for another sample. All data obtained as a result of the measurements were evaluated in the DataEXPERT program.

Radon concentrations of the water samples were calculated using the equation 1.

$$
C_{R n W}=\frac{C_{\text {air }}\left(\frac{V_{\text {system }}-V_{\text {sample }}}{V_{\text {sample }}}+k\right)-C_{o}}{1000}
$$

herein, $\mathrm{C}_{\mathrm{RnW}}$ is the radon concentration of the water sample $\left(\mathrm{Bq} \mathrm{L} \mathrm{L}^{-1}\right) ; \mathrm{C}_{\text {air }}$ is the concentration value specified in the measurement result $\left(\mathrm{Bq} \mathrm{m}^{-3}\right) ; \mathrm{C}_{0}$ is the natural background concentration $\left(\mathrm{Bq} \mathrm{m}^{-3}\right) ; \mathrm{V}_{\text {system }}$ is the interior volume of the measurement setup $(560 \mathrm{~mL}) ; \mathrm{V}_{\text {sample }}$ is the volume of the sample $(100 \mathrm{~mL})$; and $\mathrm{k}$ is the radon distribution coefficient (GENITRON INSTRUMENTS, 2007; Davutoğlu, 2008).

According to WPCR, the water of Aygir Lake was found in first class quality water (WPCR, 2004). According to RWIHC (Regulation on Water Intended for Human Consumption), the $\mathrm{pH}$ value of the water is between 6.5 and 9.5, so it is suitable for drinking water (Türkman et al., 1999; RWIHC, 2005; Emre and Kürüm, 2007). If the lake water is consumed as drinking water, the annual effective dose (AED) contribution from radon gas to the body for adults can be calculated by using equation 2 .

$$
A E D=C_{R n W} \times C_{W} \times D_{C W}
$$

herein, AED is dose exposed over a period of one year due to drinking water; $\mathrm{C}_{\mathrm{RnW}}$ is ${ }^{222} \mathrm{Rn}$ concentration in water; $\mathrm{C}_{\mathrm{W}}$ is estimated amount of water used over a year for adults $\left(730 \mathrm{~L} \mathrm{y}^{-1}\right)$; $\mathrm{D}_{\mathrm{CW}}$ is dose conversion factor $\left(3.5 \times 10^{-9} \mathrm{~Sv} \mathrm{~Bq}^{-1}\right)$.

After drinking the water goes directly to the stomach. As a result of studies conducted in water, it has been stated that if the concentration of radon in drinking water is high, it may pose a risk of cancer in the stomach. Accordingly, it is of great importance to calculate the amount of dose the stomach takes. With the help of equation 3, the dose to which the stomach will be exposed can be calculated.

$$
S E D=A E D \times W_{T}
$$

herein, SED is the annual dose that the stomach takes; $\mathrm{W}_{\mathrm{T}}$ is the weight factor used for the stomach in dose calculations $\left(\mathrm{W}_{\mathrm{T}}=0.12\right.$ ) (Prasad, 2008). The tissue weight factor used in dose calculations was taken from the report published by the ICRP in 1993 (ICRP, 1993). 


\section{RESULTS AND DISCUSSION}

The ${ }^{222} \mathrm{Rn}$ concentration results $\left(\mathrm{C}_{\mathrm{RnW}}\right)$, AED and SED values obtained after measurement and calculations in this study are given in Table 1 and Figure 5. In addition, the analysis results of the sample S-10 in the AlphaGUARD radon measurement system are given in Figure 3 to give an example.

Table 1. $\mathrm{C}_{\mathrm{RnW}}$, AED and SED values in water samples of Aygır Lake, Turkey

\begin{tabular}{cccccccc}
\hline $\begin{array}{c}\text { Sample } \\
\text { No }\end{array}$ & $\begin{array}{c}\text { Temparature } \\
\left({ }^{\circ} \mathrm{C}\right)\end{array}$ & $\begin{array}{c}\text { Humidity } \\
(\%)\end{array}$ & $\begin{array}{c}\text { Pressure } \\
(\mathrm{mbar})\end{array}$ & $\mathrm{k}$ & $\begin{array}{c}\mathrm{C}_{\mathrm{Rnw}} \\
\left(\mathrm{Bq} \mathrm{L}^{-1}\right)\end{array}$ & $\begin{array}{c}\mathrm{AED} \\
\left(\mathrm{nSv} \mathrm{y}^{-1}\right)\end{array}$ & $\begin{array}{c}\text { SED } \\
\left(\mathrm{nSv} \mathrm{y}^{-1}\right)\end{array}$ \\
\hline S-1 & 27.4 & 37.8 & 816 & 0.21 & $0.31 \pm 0.03$ & $0.79 \pm 0.08$ & $0.10 \pm 0.01$ \\
S-2 & 27.3 & 38.8 & 816 & 0.21 & $0.45 \pm 0.05$ & $1.15 \pm 0.13$ & $0.14 \pm 0.02$ \\
S-3 & 27.2 & 38.0 & 816 & 0.21 & $0.15 \pm 0.01$ & $0.38 \pm 0.03$ & $0.05 \pm 0.00$ \\
S-4 & 27.4 & 41.7 & 816 & 0.21 & $0.31 \pm 0.03$ & $0.79 \pm 0.08$ & $0.10 \pm 0.01$ \\
S-5 & 27.3 & 38.6 & 816 & 0.22 & $0.38 \pm 0.06$ & $0.97 \pm 0.15$ & $0.12 \pm 0.02$ \\
S-6 & 26.9 & 40.9 & 816 & 0.22 & $0.64 \pm 0.08$ & $1.64 \pm 0.20$ & $0.20 \pm 0.02$ \\
S-7 & 26.5 & 44.3 & 817 & 0.22 & $0.33 \pm 0.06$ & $0.84 \pm 0.15$ & $0.10 \pm 0.02$ \\
S-8 & 26.8 & 44.0 & 817 & 0.22 & $0.44 \pm 0.04$ & $1.12 \pm 0.10$ & $0.13 \pm 0.01$ \\
S-9 & 27.2 & 47.2 & 817 & 0.21 & $0.37 \pm 0.01$ & $0.95 \pm 0.03$ & $0.11 \pm 0.00$ \\
S-10 & 27.5 & 46.2 & 817 & 0.21 & $0.71 \pm 0.08$ & $1.81 \pm 0.20$ & $0.22 \pm 0.02$ \\
S-11 & 27.1 & 39.2 & 817 & 0.21 & $0.29 \pm 0.04$ & $0.74 \pm 0.10$ & $0.09 \pm 0.01$ \\
S-12 & 27.3 & 39.2 & 817 & 0.21 & $0.56 \pm 0.05$ & $1.43 \pm 0.13$ & $0.17 \pm 0.02$ \\
S-13 & 27.0 & 34.8 & 817 & 0.21 & $0.32 \pm 0.02$ & $0.82 \pm 0.05$ & $0.10 \pm 0.01$ \\
Average & $\mathbf{2 7 . 2}$ & $\mathbf{4 0 . 8}$ & $\mathbf{8 1 7}$ & $\mathbf{0 . 2 1}$ & $\mathbf{0 . 4 1} \pm \mathbf{0 . 0 5}$ & $\mathbf{1 . 0 3} \pm \mathbf{0 . 1 3}$ & $\mathbf{0 . 1 2} \pm \mathbf{0 . 0 2}$ \\
\hline
\end{tabular}

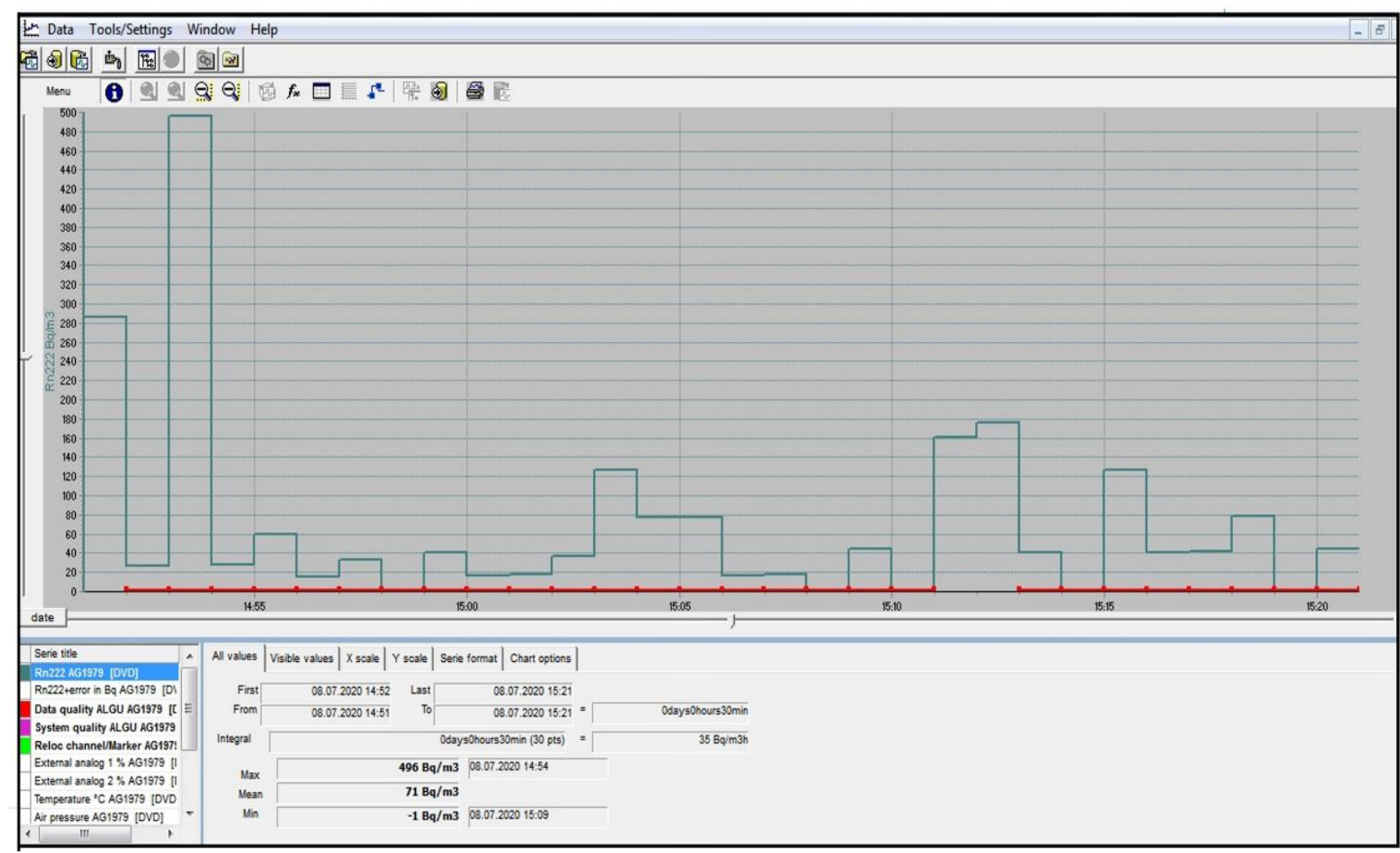

Figure 3. The analysis results of the sample S-10 in the AlphaGUARD radon measurement system 


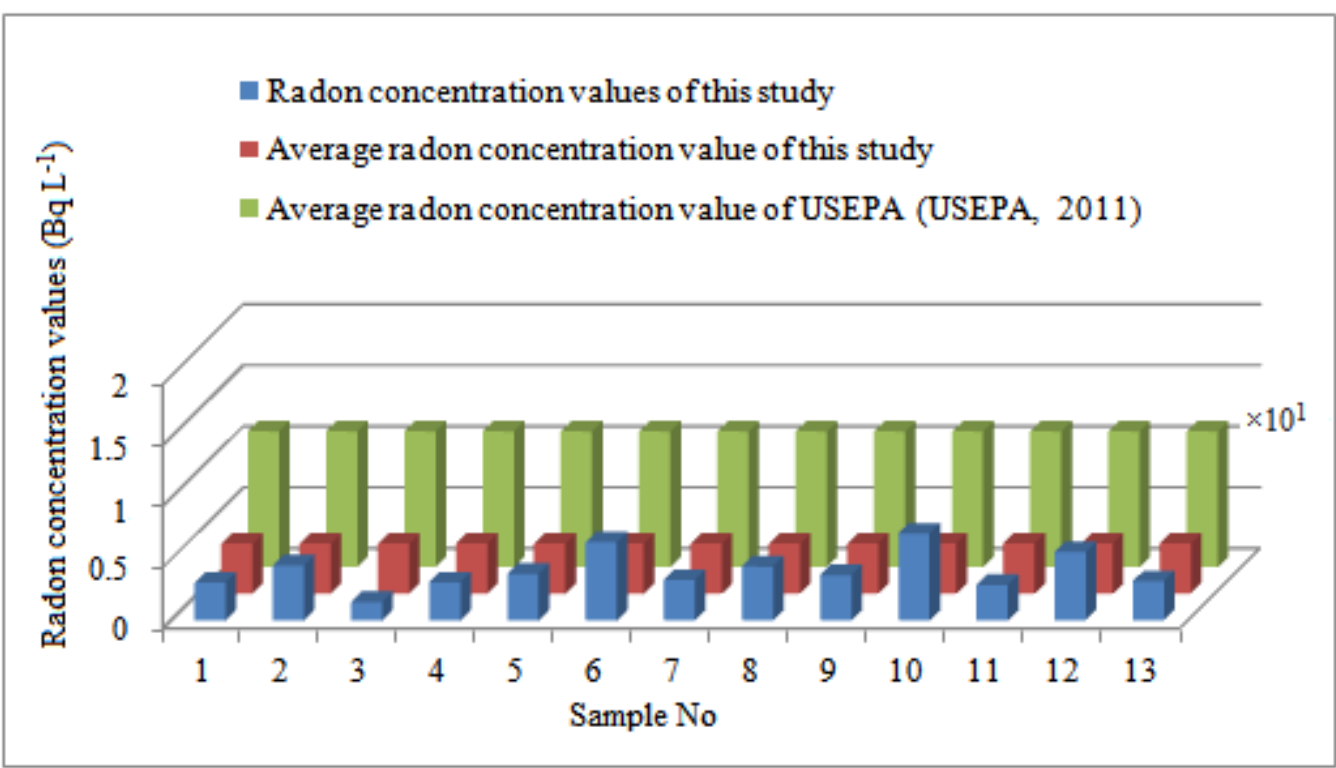

Figure 4. Radon concentration values in present study

In present research, ${ }^{222} \mathrm{Rn}$ activity concentrations of samples ranged from $0.15 \pm 0.01 \mathrm{~Bq} \mathrm{~L}^{-1}$ to $0.71 \pm 0.08 \mathrm{~Bq} \mathrm{~L}^{-1}$, with an average activity of $0.41 \pm 0.05 \mathrm{~Bq} \mathrm{~L}^{-1}$. The AED values ranged from $0.38 \pm$ $0.03 \mathrm{nSv}^{-1}$ to $1.81 \pm 0.20 \mathrm{nSv} \mathrm{y}^{-1}$, while $\mathrm{SED}$ values ranged from $0.05 \pm 0.00 \mathrm{nSv} \mathrm{y}^{-1}$ to $0.22 \pm 0.02$ $\mathrm{nSv} \mathrm{y}^{-1}$.

The $\mathrm{C}_{\mathrm{RnW}}$, AED and SED values in water samples are shown in Figure 5.

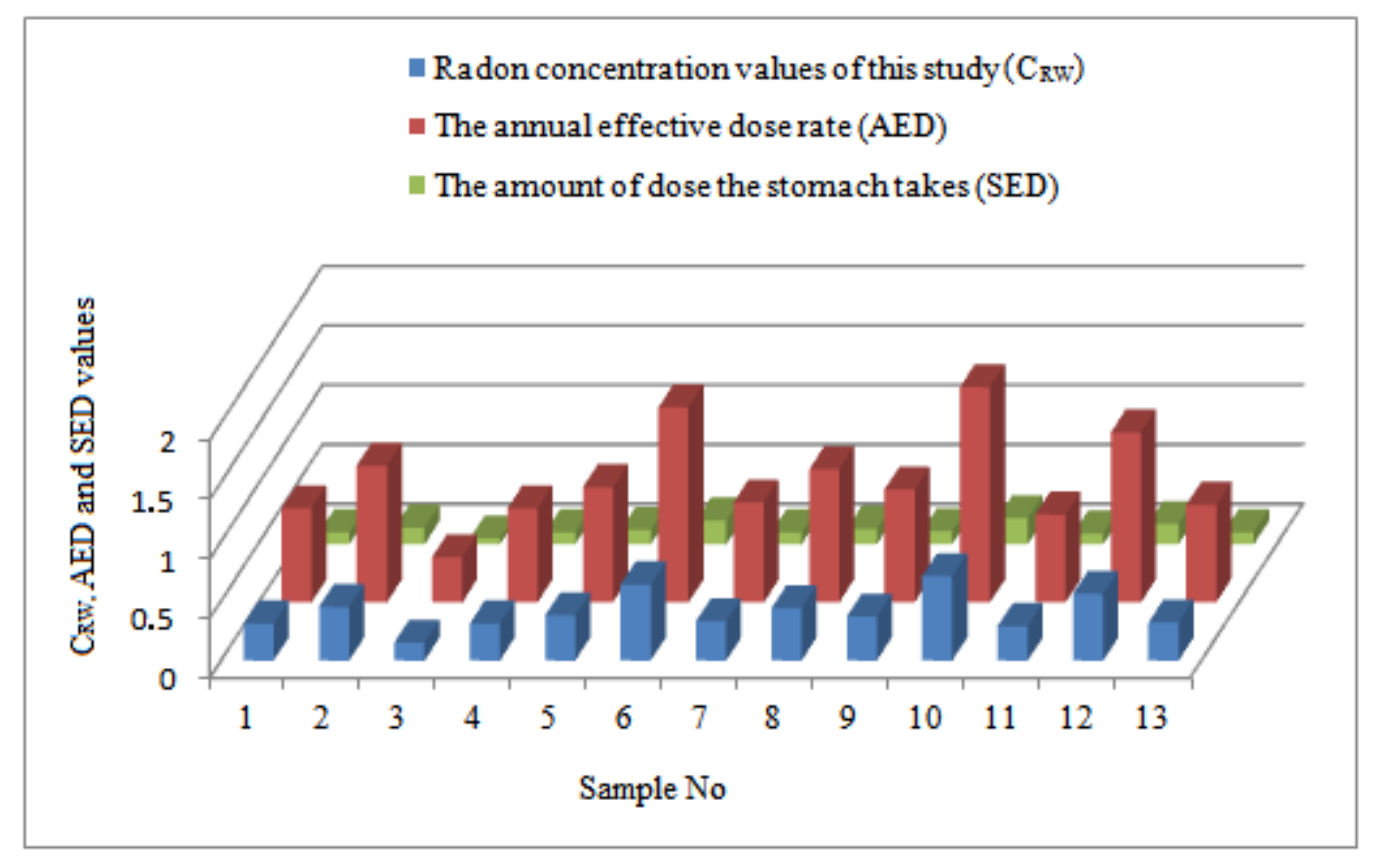

Figure 5. $\mathrm{C}_{\mathrm{RnW}}$, $\mathrm{AED}$ and $\mathrm{SED}$ values in water samples

When Table 1, Figure 4 and Figure 5 are examined together, it is seen that the lowest $\mathrm{C}_{\mathrm{RnW}}$, AED and SED values belong to the sample number $S-3$ and the highest $C_{R n W}$, AED and SED values belong to the sample number $\mathrm{S}-10$. The higher the concentration of radon in the water, the higher the AED and SED values. 
Erdoğdu (2015) collected water samples from 36 different points in the province of Osmaniye (Turkey). As a result of the measurements and calculations performed using the AphaGUARD PQ 2000 PRO radon detector, the average $\mathrm{C}_{\mathrm{RnW}}$, $\mathrm{AED}$ and $\mathrm{SED}$ were found as $0.426 \mathrm{~Bq} \mathrm{~L}^{-1}, 1.088 \mu \mathrm{Sv} \mathrm{y}^{-1}$ and $0.131 \mu \mathrm{Sv} \mathrm{y}^{-1}$, respectively (Erdoğdu, 2015).

Gyuk et al. (2017) calculated the average $\mathrm{C}_{\mathrm{RnW}}$ and AED values in 25 well water samples as 9.46 $\mathrm{Bq} \mathrm{L}^{-1}$ and $0.0721 \mathrm{mSv} \mathrm{y}^{-1}$, respectively (Gyuk et al., 2017).

In another similar study, Hussein (2020) made radon measurements in different types of drinking water samples in Egypt using nuclear track detectors (LR-115 Type II). As a result of the study, the average $\mathrm{C}_{\mathrm{RnW}}$ in water samples was determined as $0.634 \mathrm{~Bq} \mathrm{~L}^{-1}$ and the average AED value for adults was $9.953 \mu \mathrm{Sv} \mathrm{y}^{-1}$ (Hussein, 2020).

Table 2. Comparison of the average ${ }^{222} \mathrm{Rn}$ activity concentration obtained in present study with the averages obtained in similar studies and the recommended limit values

\begin{tabular}{lll}
\hline \multicolumn{1}{c}{ Lake, Country } & ${ }^{\mathbf{2 2}} \mathbf{R n}$ activity concentration $\left(\mathbf{B q ~} \mathbf{L}^{-\mathbf{1}}\right)$ & Reference \\
\hline \multirow{2}{*}{ England (English Lake District) } & $\begin{array}{l}(53.70 \pm 8.15) \times 10^{-3}- \\
(1130.74 \pm 35.92) \times 10^{-3}\end{array}$ & (Al-Masri and Blackburn, 1999) \\
\hline Darbandakhan Lake, Iraq & 18.17 & (Shivakumara et al., 2014) \\
\hline Manzala Lake, Egypt & $1.73-6.40$ & (Yousef et al., 2017) \\
\hline Çavuşçu Lake, Turkey & $0.170-32.631$ & (Tüfekcioğlu, 2015) \\
\hline Van Lake, Turkey & $(40.43 \pm 3.73) \times 10^{-3}($ Spring) & (Kayakökü and Doğru, 2020) \\
\hline WHO & $(64.94 \pm 5.99) \times 10^{-3}($ Autumn) & (WHO, 2004) \\
\hline UNSCEAR & 100 & (UNSCEAR, 1993) \\
\hline USEPA & 40 & (USEPA, 2011) \\
\hline Aygir Lake, Turkey & 11.1 & This study \\
\hline
\end{tabular}

If radon concentrations are compared for this study with studies that have been taken from lakes located in different cities and countries, it is noticed that the result values are generally lower than the results of other studies (According to Table 2).

Zorer et al. (2013) investigated the radon concentrations of the water samples taken from two points in Aygir Lake using CR-39 passive nuclear trace detectors. At the end of the study, they calculated the radon concentrations for these two points as 0.048 and $0.355 \mathrm{~Bq} \mathrm{~L}^{-1}$, respectively (Zorer et al., 2013). These values are consistent with the values obtained in the present study. In addition, radon concentration measurements were made in other lake waters in regions close to the study area. Average radon concentrations were calculated as $0.150 \mathrm{~Bq} \mathrm{~L}^{-1}$ and $0.102 \mathrm{~Bq} \mathrm{~L}^{-1}$ for Arin and Nazik Lakes, respectively, and $0.175 \mathrm{~Bq} \mathrm{~L}^{-1}, 0.106 \mathrm{~Bq} \mathrm{~L}^{-1}$ and $0.068 \mathrm{~Bq} \mathrm{~L}^{-1}$ for Ilık Lake, Soğuk Lake and Kara Lake respectively, which are from the Nemrut Lakes (Zorer et al., 2013). These results are lower than the average value obtained in present study, $0.41 \pm 0 . \mathrm{Bq} \mathrm{L}^{-1}$.

Kayakökü and Doğru (2020) calculated the radon concentrations in Van Lake surface water samples. Experimental studies were carried out using CR-39 passive radon trace detectors and Radosys radon measurement system. The average radon concentration was calculated as $0.040 \mathrm{~Bq} \mathrm{~L}^{-1}$ in spring, whereas as $0.065 \mathrm{~Bq} \mathrm{~L}^{-1}$ in autumn (Kayakökü and Doğru, 2020). Likewise, these average values are lower than the values obtained in this study.

Differences in meteorological parameters may cause different radon content in samples. The rock types of Bitlis and its districts are generally composed of limestone and magmatic granite, granitic gneiss, andesite, decides and some of their features are shaped by basaltic lavas (Bal et al., 2017). When water touches rocks throughout the medium they pass through, some substances are dissolved and carried by the water. Aygır Lake is located on the south side of Süphan Mountain and it is a tectonically 
formed lake. In addition, fault lines pass through the land where the lake is located. This may be the reason for the high concentration of radon in the lake.

\section{CONCLUSION}

In this study, the radon concentrations were measured by using the Saphymo Gmbh AlphaGUARD Professional radon monitor in Bitlis Eren University Physics Department. While the lowest $\mathrm{C}_{\mathrm{RnW}}$, AED and SED values belong to the $S-3$ sample, the highest $C_{R n W}$, AED and SED values belong to the $S-10$ sample. The southern part of the lake is Pliocene sedimentary units, the western part is Miocene sedimentary units, northern and eastern sections are surrounded by lava flows $(760 \pm 40-150 \pm 40) \times 10^{3}$ years old (Özdemir et al., 2016). In addition, Süphan Volcanic Mountain is located in the northern part of the lake and there is also a fault line passing through the north of the lake. S-3 point, where radon activity is the lowest, is a flat area in the southwestern part of the lake, and is located on the right side of the highway to Aygir village. S-10 point, where radon activity is highest, is in the northeastern part of the lake and this is the mountainous area. This place is close to both the Süphan Mountain and the fault line. It is also a point close to the area where people go for picnics. This region is a region where intensive agricultural activities are carried out. The fact that this area is surrounded by $(760 \pm 40-150 \pm 40) \times 10^{3}$ years old lava flows and the soil structure can be shown among the reasons that affect the high radon level. Radon concentrations obtained from the calculations determined to be lower than $100 \mathrm{~Bq} \mathrm{~L}^{-1}, 40$ $\mathrm{Bq} \mathrm{L}^{-1}$ and $11.1 \mathrm{~Bq} \mathrm{~L}^{-1}$, which are the limit values for drinking water set by World Health Organization (WHO), United Nations Scientific Committee on the Effects of Atomic Radiation (UNSCEAR) and the US Environmental Protection Agency (USEPA).

When the dose taken as a result of ingestion of radon in drinking water is examined, it is seen that the amount of dose changes according to the radon concentration. The International Atomic Energy Agency (IAEA) and World Health Organization (WHO) have determined the total dose for the dose taken from drinking water in one year; this value is $0.1 \mathrm{mSv}^{-1}\left(10^{5} \mathrm{nSv} \mathrm{y}^{-1}\right)$ (IAEA, 2002; WHO, 2004). When the results obtained in this study are compared with this limit value, it is seen that the results are below this limit value. Therefore, the ${ }^{222} \mathrm{Rn}$ concentration values determined in the waters of Aygir Lake do not cause any harm to health.

The data obtained as a result of this study show that using the Aygir Lake water in agriculture (irrigation etc.) and fish farming will not result in radiological hazard. Additionally, the natural and artificial radionuclide concentrations and heavy metal contents of the lake can be determined by doing a more detailed study.

\section{ACKNOWLEDGEMENTS}

I would like to thank Prof. Dr. Sezai YALÇIN and Assoc. Prof. Sultan ŞAHIN BAL for sharing their knowledge and experiences with me during the measurement and analysis processes.

\section{Conflict of Interest}

I declare that there is no conflict of interest during the planning, execution and writing of the article.

\section{Author's Contributions}

I hereby declare that the planning, execution and writing of the article was done by me as the sole author of the article.

\section{REFERENCES}

Al-Masri MS, Blackburn R, 1999. Radon-222 and related activities in surface waters of the English Lake district. Applied Radiation and Isotopes 50(6): 1137-1143. 
Bal SŞ, K1lıç Ö, Gönültaş F, 2017. Determination of radon concentration on the Bitlis spring waters. Sakarya University Journal of Science 21(3): 302-306.

Baykara O, Doğru M, 2006. Measurements of radon and uranium concentration in water and soil samples from east anatolian active fault systems (Turkey). Radiation Measurements 41(3): 362-367.

Çavuş A, 2018. An investigation on water quality and management of Aygır Lake. Van Yüzüncü Yıl University Graduate School of Natural and Applied Sciences, PhD. Thesis.

Çevik U, Damla N, Karahan G, Çelebi N, Kobya Aİ, 2006. Natural radioactivity in tap waters of eastern Black Sea region of Tukey. Radiation Protection Dosimetry 118(1): 88-92.

Davutoğlu H, 2008. Methods of radon gas measurement. Dumlupınar University Graduate School of Natural and Applied Sciences Master Thesis.

Doğu AF, Deniz O, 2015. Morphologic features and tourism facilities of Aygır Lake. Journal of International Social Research 8(41): 692-702.

Emre Y, Kürüm V, 2007. Trout Farming in Pools and Cages. Posta Printing House No:272, Seyrantepe, İstanbul. Erdoğdu M, 2015. Determination of radon (Rn-222) concentration in drinkable and processed water in and around Osmaniye. Osmaniye Korkut Ata University Institute of Science, Master Thesis.

Erees FS, Yener G, Salk M, Özbal Ö, 2006. Measurements of radon content in soil gas and in the thermal waters in western Turkey. Radiation Measurements 41(3): 354-61.

GENITRON INSTRUMENTS, 2001. AlphaPUMP Technical Description. Genitron Instruments GmbH HeerstraBe No: 149, pp. 6-7, Germany.

GENITRON INSTRUMENTS, 2007. AquaKIT Accessory for Radon in Water Measurement in Combination with the Radon Monitor AlphaGUARD. Genitron Instruments GmbH HeerstraBe No: 149, pp.15, Germany.

Genrich V, 2006. AlphaGUARD PQ2000/MC50. Multiparameter Radon Monitor, Characterisation of its Physical Properties Under Normal Climatic and Severe Environmental Conditions, Genitron Instruments GmbH. User Manual, Frankfurt, Germany.

George AC, 2007. "World history of radon research and measurement from the early 1900s to today." Natural Radiation Environment Conference VIII (NRE VIII) in Buzios, Brazil, Radon Bulletin of the CRCPD, reprinted in November 2007.

Gosink TA, Baskaran M, Holleman DF, 1990. Radon in the human body from drinking water. Health Physics 59(6): 919-920.

Gyuk PM, Aruwa A, Dogara MD, Daniel IH, 2017.Annual effective dose of Radon-222 in well water samples in male adults: Idah, Nigeria American Journal of Optics and Photonics 5(4): 45-49.

Hussein AS, 2019. Evaluation of the radiation dose from radon ingestion from different types of drinking water samples in Egypt using nuclear track detectors (LR-115 Type II). Radiat Prot Environ 42: 168-72.

IAEA, 2002. International Atomic Energy Agency. Specification of Radionuclide Content in Comities Requiring Regulation for Purposes of Radiation Protection Safety Guide.

ICRP, 1994. International Commission on Radiological Protection, Protection Against Radon-222 at Home and at Work. Pergamon Press ICRP Publication No:65, pp. 45.

Karahan G, Öztürk N, Bayülken A, 2000. Natural radioactivity in various surface waters in İstanbul. Water Research 34(18): 4367-4370.

Kayakökü H, Dogru M, 2020. Radon concentration measurements in surface water samples from Van Lake, Turkey using CR-39 Detectors. Bitlis Eren University Journal of Science and Technology 10(1): 35-42.

Meisenberg O, Mishra R, Joshi M, Gierl S, Rout R, Guoa L, Agarwal T, Kanse S, Irlinger J, Sapra BK, Tschiersch $\mathrm{J}$, 2017. Radon and thoron inhalation doses in dwellings with earthen architecture: comparison of measurement methods. Science of the Total Environment 579: 1855-1862.

Nikolopoulos D, Vogiannis E, Petraki E, Zisos A, Louizi A, 2010. Investigation of the exposure to radon and progeny in the thermal Spas of Loutraki (Attica-Greece): Results from measurements and modelling. Science of the Total Environment 408(3): 495-504. 
Özdemir Y, Akkaya İ, Oyan V, Kelfoun K, 2016. A debris avalanche at Süphan Stratovolcano (Turkey) and implications for hazard evaluation. Bulletin of Volcanology 78(9): 1-17.

Prasad G, Prasad Y, Gusain GS, Ramola RC, 2008. Measurement of radon and thoron levels in soil, water and indoor atmosphere of Budhakedar in Garhwal Himalaya, India. Radiation Measurements 43: 375-379.

RWIHC, 2005. Regulation on Water Intended for Human Consumption, O.G. date: 17 Feb 2005, O.G. number: 25730. O.G. Annex 1 (Amended attachment: RG-7/3/2013-28580). Ministry of Health http://shsm.gov.tr. (Date of access: 25 July 2020).

Shivakumara BC, Chandrashekara MS, Kavitha E, Paramesh L, 2014. Studies on ${ }^{226}$ Ra and ${ }^{222}$ Rn concentration in drinking water of Mandya region, Karnataka State, India. Journal of Radiation Research and Applied Sciences 7(4): 491-498.

Şahin S, 2004. Determination of gross alpha and gross beta radioactivity levels of Kangal (Sivas) Fish Spa. Firat University Graduate School of Natural and Applied Sciences, Master Course Seminar.

Tanriverdi E, 2016. Determination of radon activity in waters in the Bitlis region. Bitlis Eren University Graduate School of Natural and Applied Sciences, Master Thesis.

Tarim UA, Gurler O, Akkaya G, Kilic N, Yalcin S, Kaynak G, Gundogdu O, 2011. Evaluation of radon concentration in well and top waters in Bursa. Radiation Protection Dosimetry 150(2): 207-212.

Tebbutt THY, 1998. Principles of Water Quality Control (Fifth Edition). Elsevier Ltd. ISBN: 978-0-7506- 36582.

Tüfekcioğlu F, 2015. The measurement of radon concentration and investigation of discontinuities. Selçuk University Graduate School of Natural and Applied Sciences PhD. Thesis.

Türkman A, Tokgöz S, Sarptaş H, 1999. Drinking water standards and safe drinking water. 3rd National Environmental Engineering Congress, İzmir, November. 25-26, 1999.

UNSCEAR (United Nations Scientific Committe on the Effects of Atomic Radiation), 1993. Report to the General Assembly, with Scientific Annexes. United Nations Sales Publication E.94.IX.2. United Nations, New York.

Urban M, Piesch E, 1981. Low-level environmental radon dosimetry with a passive track etch detector device. Radiation Protection Dosimetry 1(2): 97-109.

USEPA (U.S. Environmental Protection Agency), 2011. Proposed Radon in Drinking Water Regulation. DC, EPA: 600/R-09/ 052F.

Valkovic V, 2000. Radioactivity in the environment. Elsevier Science B.V. Netherlands.

Yalcin S, Gurler O, Akar UT, Incirci F, Kaynak G, Gundogdu O, 2011. Measurements of radon concentration in drinking water samples from Kastamonu (Turkey). Isotopes in Environmental and Health Studies 47(4): 438-445.

Yousef HA, El-Farrash AH, Magdy A, 2017. Radon levels in surface water samples from Manzala Lake East Nile Delta, Egypt using Nuclear Track Detectors. Journal of Nuclear and Particle Physics 7(2): 36-42.

WHO (World Health Organization), 2004. Guidelines for Drinking Water Quality Recommendations, 1: 206-209. WPCR, 2004. Water Pollution Control Regulation, http://mevzuat.basbakanlik.gov.tr/ Metin.Aspx ?MevzuatKod=7.5.7221\&sourceXmlSearch=\&MevzuatIliski=0. (Date of access: 25 July 2020).

Zorer ÖS, Şahan T, Ceylan H, Doğru M, Şahin S, 2013. ${ }^{238} \mathrm{U}$ and ${ }^{222} \mathrm{Rn}$ activity concentrations and total radioactivity levels in lake waters. Journal of Radioanalytical and Nuclear Chemistry 295(3):1837-1843. 